\title{
Publicações do Serviço de Documentação do DASP
}

\section{OBRAS EDITADAS A PARTIR DE 1965}

Circulares da Presidência da República - de $1959^{\circ}$ a 1964.

Circulares da Presidência da República — de 1965.

Prontuário de Redação Oficial - João Luiz Ney - $4^{a}$ edição.

Estatuto dos Funcionátios Civis da União e Legislação Regulamentadora - Lei $\mathrm{n}^{\circ} 1.711$ de 28 de outubro de 1952. Noções Básicas de Análise - João Luiz
Ney.

Manual de Serviço dos Processos das Perısões Civis do Tesouro Nacional Wérie Manuais de Serviço Wanderley T. Viana e Olavo $\bar{P}$.

Órgãos da Administração Federal (Arrolamentos e subordinação, incluindo: Interpol, Poder Legislativo e Poder
Judiciário).

Promoção, Acesso, Transferência e Remoşão dos Funcionários Públicos Civis da União - Decretos Números 53.480 de 23-1-64; 54.488, de $15-10-64$ e 53.481 de 23-1-64.

Exposição de Motivos N* GB 25, de 1-4-66 - Normas e critérios elaborados pela COTIDE para aferição da essencialidade, complexidade e grau de responsabilidade de atribuições, e para investigação das condições do mercado de trabalho e conseqüentes dificuldades de recrutamento para determinados cargos.

Indice da Revista do Serviço Público do ano XXV - 1962.
Municipio e Municipalização $-1^{\circ}$ edição - Manoel de Oliveira Franco Sobrinho.

Censo dos Servidores Públicos Civis da União e das Autarquias - Decreto $N^{\circ} 58.297$ de 2-5-66. - Estabelece normas para execução do censo dos servidores Civis da União e das Autarquias.

Aspectos de Relações Públicas - Sylla M. Chaves - $2^{a}$ edição - Seção de Publicações - S. D. - DASP - 1966.

Mantial de Simplificação do Trabalho - José Rodrigues de Senna - $2^{2}$ edição - Seção de Publicações S. D. - DASP - 1966.

Ementário de Decisões Administrativas - Pareceres do Consultor-Geral da República, do Consultor Juridico do DASP e da Divisão do Regime Juridico de Pessoal do DASP 1966 - vol. 6.

Estudos de Promoção e Acesso - Série "Ensaios de Administração» $\mathrm{n}^{\circ} 21$ - José Medeiros - 1966.

Classificação de Cargos de Nivel Superior - Legislação e Jurisprudência atualizada até 30-9-66. Seção de Publicações - S. D. - DASP 1966.

O Comportamento do Individuo na Organização - Caetana Myrian $\mathrm{Pa}$ rente Cavalcante.

Readaptação - Decreto $\mathrm{n}^{\circ} 57.460$ de 20-12-65 e Decreto $\mathrm{n}^{\circ} 57.461$ de 20-12-65.

Instruções Sôbre Processamento das Readaptações - Resolução GB-2 de 19-12-66 - Expedida pela Comis 
são de Classificação de Cargos Seção de Publicações - S. D. DASP - 1967.

Revisão Tipográfica - R. P. Azambuja.

História Administrativa do Brasil Vols. I, II, IV e VI, Administração de Material, Vols. I e II - Oscar Victorino Moreira.

Das Concorrências e Coleras de Preços - Oscar Victorino Moreira.

Um Curso de Relações Públicas no DASP - Série $\mathrm{n}^{\circ} 3$ - Esc. de Serv. Públ.

Reajustamento Salarial dos Servidores Civis e Militares e Gratificação pela Representação de Gabinete.

DASP como um Imperativo Democrático e Técnico - C. A. Lúcio Bitencourt - Serviço de Documentação - DASP - 1966.

Lei $n^{0} 4.345$ de 26-6-64 - Institui novos valôres para os vencimentos dos Servidores Públicos Civis do Poder Executivo e dá outras providências.

Lei $n^{\circ} 4.348$ de 26-6-64 - Estabelece normas processuais relativas a Mandado de Segurança.

Lei $n^{\circ} 4.863$ de 29-11-65 - Reajusta os vencimentos dos Servidores civis e militares, altera as aliquotas dos impostos de renda, importação, consumo e sêlo e da quota de previdência social, unifica contribuições baseadas nas fôlhas de salário, e dá outras providências.

Lei $n^{\circ} 4.863$ de 29-11-65 - Tabelas de Vencimentos dos Servidores Públicos Federais civis e militares, dos membros do Ministério Público Federal e Serviço Jurídico da União, inclusive cotas de salário-familia e, ainda, tabelas de funções Gratificadas e Cargos em Comissão - D. O. de 30-11-65 - Suplemento $n^{\circ} 228$.
Lei $n^{\circ}$ 4.881-A de 6-12-65 - Dispõe sôbre o Estatuto do Magistério Superior $-D$. O. de 10-12-65.

Decreto $n^{\circ} 54.061$ de 28-7-64 - Regulamenta o Regime de Tempo Integral previsto nos arts. 11 e 12 da Lei $n^{\circ} 4.345$ de 26-6-64, e Dec. $n^{\circ} 56.730$ de 16-8-65 - Altera o decreto anterior $-D$. O. de 17-8-65.

Decreto $n^{\circ} 56.887$ de 20-9-65 - Altera - Regimento da Comissão de Classificação de Cargos - D. O. de 23 de setembro de 1965. - Seção I.

Decreto-lei $n^{\circ} 1$ de 13-11-65 - Institui o Cruzeiro Nôvo e dá outras providências.

Decreto $n^{\circ} 60.190$ de 8-2-67 - Regulamenta o Dec. - Lei $n^{9} 1$ de 13-11-65.

Decreto $n^{\circ} 57.630$ de 14-1-66 - Dispõe sôbre Nomeação e Admissão de Pessoal para o Serviço Público $\mathrm{Fe}$ deral $-D$. O. de 17-11-66.

Decreto $n^{\prime} 57.744$ de 3-2-66 - Regulamenta o Regime de Tempo Integral e Dedicação Exclusiva $-D$. $O$. de 17-2-66.

Depoimentos Sôbre o DASP Serviço de Documentação - 1966.

Indicador dos Pareceres da Comissão de Acumulação de Cargos - Volume IV - Seção de Publicações do Serviço de Documentaçấo do DASP - 1967.

Promoção: Idéias e Sugestões para um nôvo Sistema no Serviço Público Federal. Série: Escola de Serviço Público - 4.

Reajustamento Salarial dos Servidores Civis e Militares da União, Gratificação pela Representação de $\mathrm{Ga}$ binete e Regulamentação do Regime de Tempo Integral e Dedicação Exclusiva - Seção de Publicações do Serviço de Documentação do DASP - 1967. 